\title{
ELECCIONES PRESIDENCIALES 2003 EN LA REPÚBLICA ARGENTINA: CRÓNICA DE UN RESULTADO ANUNCIADO
}

POR

ADRIANATETTAMANTI DE RAMELLA 


\section{SUMARIO}

I. INTRODUCCIÓN. ACTOS PREELECTORALES. CONVOCATORIA A ELECCIONES PRESIDENCIALES PARA EL PERÍODO 2003-2007. II. EleCCIONES PRESIDENCIALES EN LA REPÚBLICA ARGENTINA: ANTECEDENTES CONSTITUCIONALES Y LEGALES. III. LA REFORMA CONSTITUCIONAL de 1994: Segunda Vuelta electoral. IV. Corolario: Renuncia Y proclaMACIÓN. V. PRINCIPALES MEdidAS del GOBIERNo dURANTE EL PRIMER AÑo DE SU MANDATO: a) Acerca de la atribución para designar los magistrados de la Corte Suprema de Justicia de la Nación. b) Acerca de los decretos de necesidad y urgencia: una práctica consolidada. VI. ReFLEXIÓN fINAL. 


\title{
ELECCIONES PRESIDENCIALES 2003 EN LA REPÚBLICA ARGENTINA: CRÓNICA DE UN RESULTADO ANUNCIADO (*)
}

POR

\author{
ADRIANA TETTAMANTI DE RAMELLA(**)
}

\section{INTRODUCCIÓN. ACTOS PREELECTORALES. CONVOCATORIA A ELECCIONES PRESIDENCIALES PARA EL PERIODO 2003-2007}

En la República Argentina, durante el año 2003, al mismo tiempo que celebrábamos veinte años de vigencia ininterrumpida de vida democrática,

(*) El artículo ha sido escrito especialmente para la Revista de Derecho Político de la UNED, agradeciendo al distinguido Profesor Dr. JAVIER TAJADURA TEJADA por la gentil invitación a colaborar en tan prestigiosa publicación.

(**) Abogada. Posgraduada de la Especialización en Derecho Procesal, con mención en Derecho Procesal Civil, Universidad Católica de Cuyo, San Juan, Argentina: Profesora Adjunta Efectiva de Derecho Constitucional y de Práctica Procesal Civil de la Facultad de Derecho y Ciencias Sociales de la Universidad Católica de Cuyo, San Juan; Argentina. Miembro asociado de la Asociación Argentina de Derecho Constitucional! Miembro correspondiente del Instituto de Estudios de Derecho Administrativo; Mendoza, Argentina. Secretaria Académica del Instituto de Derecho Constitucional y Procesal Constitucional del Foro de Abogados de San Juan, Argentina. Autora y coautora de artículos sobre Derecho Constitucional, Administrativo y Procesal, publicados en obras colectivas y revistas jurídicas especializadas. Desde 1991 integra el Cuerpo de Abogados del Estado Nacional. 
y luego de un proceso de inestabilidad institucional desencadenado particularmente a partir de diciembre del año 2001 , se convocaba a la renovación de Presidente y vicepresidente, como así también de diputados $y$ senadores nacionales.

La Nación Argentina ha adoptado el sistema presidencialista. El cargo de Presidente de la República se creó por el Congreso Constituyente de 1824, por ley del 6 de febrero de $1826^{1}$, y nombrado presidente Bernardino Rivadavia. Se mantuvo ese cargo en la Constitución de 1826 y, luego, en las sucesivas constituciones argentinas desde 1853. Además de estos antecedentes institucionales, debe señalarse el pensamiento de Alberdi, quien inspirándose en la institución del virrey y en la Constitución de Chile de 1833, abogó por un poder ejecutivo fuerte encuadrado dentro de facultades constitucionales².

$Y$ si bien es cierto que nuestro constitucionalismo ha diseñado un régimen de colaboración de poderes, antes que de división de poderes, no es menos cierto que ha otorgado al Poder Ejecutivo una preeminencia notoria, que se ha acentuado en la práctica institucional. Acerca del tema, Dromi y Menem comentan: "La Constitución de 1853-60 estableció una división formal del poder. No obstante, el Poder Ejecutivo se erigió en el poder fuerte por excelencia, característica heredada, sin duda, del derecho español y de la situación política social que vivía el país al momento de su sanción” ${ }^{3}$.

Sagüés, en el sentido expuesto, expresa que "Latinoamérica, en general, y la Argentina, en particular, han hipertrofiado al Poder Ejecutivo, a quien se lo puede calificar como un César republicano. Las razones de este desmesurado crecimiento son tanto normativas (imputables a la Constitución) como sociológicas» 4 . Se ha sostenido que «la reforma constitucional de 1994 fue un intento que no alcanzó a morigerar el hiperpresidencialismo en nuestro país. El comportamiento real del poder frente a las novedades constitucionales es un dato muy interesante a evaluar. Sobre todo cuando notamos que el principio de separación de poderes, para evi-

1 "Asambleas Constituyentes Argentinas", t. II. págs. 550 y 667.

2 Ramella, Pablo Antonio, Derecho Constitucional, 2. edición actualizada, Ediciones Depalma, Buenos Aires, 1982, pág. 735.

3 DROMI, Roberto y MENEM, Eduardo, La Constitución reformada comentada, interpretada y concordada, Ediciones Ciudad Argentina, Buenos Aires, Argentina, 1994, pág. 305.

${ }^{4}$ SAgües, Néstor Pedro, Elementos de Derecho Constitucional, Tomo 1, 3. ${ }^{\circ}$ edición actualizada y ampliada, $1 .^{\circ}$ reimpresión, Editorial Astrea, Ciudad de Buenos Aires, Argentina, 2001, pág. 540. 
tar el abuso de los gobernantes, pasa a ser irrelevante cuando los mismos poderes han dejado de cumplir con sus atribuciones constitucionales. En nuestro país, en base a un "prudente realismo jurídico» según reclama Bidart Campos, o con "realismo institucional» en palabras de Linares Quintana, debemos destacar que, desde un punto de vista práctico, la tensión entre los poderes fundamentales del Estado se ha vuelto a menudo insostenible ${ }^{5}$.

Observa Barraza que «[...] la historia argentina, desde 1860, se estudia sobre la base de las sucesivas personas que han detentado el cargo de Presidente de la Nación. Asimismo, cuando se habla de gobierno, si bien. es cierto que comprende a los tres órganos, Ejecutivo, Legislativo y Judicial, siempre se alude al gobierno de la persona que en ese momento ostenta la titularidad del Poder Ejecutivo. De la misma forma, cuando el: ciudadano endilga su malestar hacia el gobierno lo hace sobre la persona। del presidente, olvidando que existen dos órganos más que comprenden al gobierno argentino. [...] es el Poder Ejecutivo el que atrae la atención de los ciudadanos y en quien el hombre común deposita sus mayores esperanzas y expectativas; se produce entonces la personalización del poder ${ }^{6}$.

Ni siquiera la incorporación de la figura del Jefe de Gabinete de Ministros ${ }^{7}$, con la reforma constitucional de 1994, logró atenuar el presi-. dencialismo vigoroso en nuestro país.

La elección del Presidente en la República Argentina, bien se puede: advertir, es de vital importancia para la vida del país; no es un hecho baladi, sino que, más bien, suscita pasiones $y$ desencuentros; $y$ en las elecciones del año 2003 no faltaron pasajes que discurrieran en el ánimo exaltado y la efervescencia de la contienda.

5 Riberi, Pablo, "El presidencialismo exánime», en la obra colectiva Constitución de la Nación Argentina, con motivo del sesquicentenario de su sanción, Tomo II, Asociación Argentina de Derecho Constitucional, Talleres Gráficos Lux S.A., Santa Fe, Argentina, 2002, pág. 312.

6 En el segundo dictamen del Consejo para la Consolidación de la Democracia (pág. 15) se dijo que la psicología social hispánica se materializa en la permanente búsqueda de caudillos (BARRAZA, Javier Indalecio - Schafrik, Fabiana, El Jefe de Gabinete de Ministros, Ed. Abeledo - Perrot, Buenos Aires, Argentina, 1999. pág. 66).

7 La Ley de declaración de la necesidad de la reforma $n .^{\circ} 24.309$ expresa en su "Núcleo de Coincidencias Básicas, Pto. A»: Atenuación del sistema presidencialista: Se promueve la creación de un Jefe de Gabinete de Ministros, nombrado y removido por el Presidente de la Nación, con responsabilidad política ante el Congreso de la Nación, que podrá también removerlo mediante un voto de censura. a) Sus atribuciones serán: 1. Tener a su cargo la administración general del pais. [...]". La previsión quedó consagrada en el art. 100 de la Constitución Nacional. 
Previo a la realización de las elecciones presidenciales, deben cumplirse una serie de actos preelectorales, que están contemplados en el Código Electoral Nacional y en la Ley Orgánica de los Partidos Políticos. La Ley $\mathbf{N}^{\circ}$ 19.945, que sanciona el Código Electoral Nacional ${ }^{8}$, establece las condiciones para ser elector ${ }^{9}$, el deber de votar y sus exenciones ${ }^{10}$, el secreto del voto durante todo el desarrollo del acto electoral $^{11}$, y la convocatoria a elecciones, que en el caso de las presidenciales y cargos nacionales, deben ser dispuestas por el Poder Ejecutivo Nacional ${ }^{12}$.

8 Ley No 19.945 (Anales de Legislación Argentina -Adla- XLIII-C-2815; texto ordenado por Decreto n. ${ }^{\circ}$ 2.135, de 1983) El Decreto del Poder Ejecutivo Nacional N. ${ }^{\circ}$ 2.135 (Boletín Oficial del 6/9/1983) aprueba el texto ordenado del Código Electoral Nacional (Ley N. ${ }^{\circ} 19.945$, con las modificaciones introducidas por las Leyes $\mathrm{N} .{ }^{\circ} 20.175$, 22.838 y 22.864). El Código Electoral Nacional ha sido modificado en diversas oportunidades a fin de adecuarlo a las enmiendas que se suscitaron en materia electoral. La última modificación -introducida mediante Ley 25.858 (sancionada el 4/12/2003 y promulgada el 29/12/2003 - B.O. n. ${ }^{\circ} 30.311$ ) - incorpora algunas peculiaridades con relación a las calidades personales de los electores (las personas que tuvieran alguna imposibilidad para efectuar todos o algunos de los movimientos propios para sufragar, podrán ser acompañadas por el presidente de mesa al cuarto oscuro para colaborar con los pasos necesarios hasta la introducción del voto, en la medida que la discapacidad lo requiera; las personas mayores de 70 años, que hayan sido designadas como autoridades de mesa, podrán excusarse de dicha carga pública justificando únicamente su edad; los procesados que se encuentren con cumpliendo prisión preventiva, tendrán derecho a emitir su voto [esta cuestión ya había sido resuelta por la Corte Suprema de Justicia de la Nación, en la causa "Mignone, Emilio Fermín s/ Amparo", en la cual declaró la inconstitucionalidad del inciso d) del art. $3 .^{\circ}$ del Código Electoral Nacional [ que disponía la prohibición de votar a los detenidos por orden de juez competente, aún sin condena por sentencia firme], fundamentado - principalmente - en el art. 23.2 de la Convención Americana de Derechos Humanos - con jerarquía constitucional de acuerdo a lo dispuesto en el art. 75 inc. 22) de la Constitución Nacional, a partir de su reforma de 1.994 - Fallo publicado en La Ley, Buenos Aires, Argentina, 14 de agosto de 2.002).

${ }^{9}$ El artículo 1. ${ }^{\circ}$ dispone que: «Son electores nacionales los ciudadanos de ambos sexos, nativos, por opción y naturalizados, desde los dieciocho (18) años cumplidos de edad, que no tengan ninguna de las inhabilidades previstas en esta ley. La calidad de elector, a los fines del sufragio activo, se prueba por su inclusión en el Registro Electoral». El articulo $3 .^{\circ}$ menciona las personas excluidas.

${ }^{10}$ Establecido en el artículo $122^{\circ}$.

$"$ Dispuesto en los articulos $13^{\circ}$ y $85^{\circ}$.

12 El artículo 53. ${ }^{\circ}$ establece que la convocatoria debe hacerse con noventa (90) días por lo menos de anticipación y expresará: 1) Fecha de elección; 2) Clase y número de cargos a elegir; 3) Número de candidatos y los que pueden votar al elector; 4) Indicación del sistema electoral aplicable. 
La Ley Orgánica de Partidos Políticos N. ${ }^{\circ} 23.298^{13}$ fue modificada por

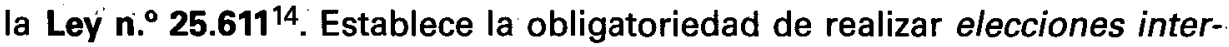
nas abiertas simultáneas, que regirá por primera vez para las elecciones: presidenciales y de renovación legislativa a realizarse en el año $2.003^{15}$. El artículo 29 bis de la Ley N. 23.298 (incorporado por la Ley n. ${ }^{\circ} 25.611$, art. $4 .{ }^{\circ}$ ). establece que "En los partidos políticos o Alianzas Electorales Nacionales, la elección de los candidatos a presidente y vicepresidente, así como la de: los candidatos a diputados y senadores nacionales, se realizará a través de: internas abiertas. La fecha de la elección deberá ser comunicada por el, Juzgado Federal con competencia en cada distrito. La elección de los candidatos a presidente y vicepresidente se hará por fórmula y será proclama-. da la candidatura de la fórmula presidencial que haya obtenido la mayoría: simple de votos afirmativos válidos emitidos".

Las elecciones para autoridades partidarias y para elegir candidatos a cargos electivos, salvo para el cargo de presidente $y$ de vicepresidente de la Nación y de legisladores nacionales, se rigen por la carta orgánica, subsidiariamente por la Ley $\mathrm{N} .^{\circ} 25.611 \mathrm{y}$, en lo que resulte aplicable, por la legislación electoral. Las elecciones para candidatos a presidente, vicepresidente $y$ a legisladores nacionales, se rigen por lo dispuesto en la Ley N. ${ }^{\circ}$ 25.611 y, subsidiariamente, por la ley electoral ${ }^{16}$.

El Decreto n. ${ }^{0} 1397 / 02^{17}$, del 5/8/2002, fija las pautas que han de regir las elecciones abiertas simultáneas. Las agrupaciones políticas intervienen'

13 Adla XLV-D-3635.

14 Ley N. ${ }^{\circ} 25.611$ fue sancionada el $16 / 9 / 2002$, promulgada con veto parcial por Decreto $n^{\circ} 1.169 / 02$ y publicada en el Boletín Oficial del 04/07/2002 (Adila LXII-C-2901).

15 Artículo 29 bis de la Ley N. 23.298 incorporado por el art. $4 .^{\circ}$ de la Ley N. ${ }^{\circ}$ 25.611, en concordancia con el artículo 53 del Código Electoral Nacional, y art. $7^{\circ}$ de la Ley N. ${ }^{\circ} 25.611$.

${ }^{16}$ Cfr. Ley N. ${ }^{\circ} 25.611$, art. $3 .^{\circ}$, que modifica el art. 29 de la Ley Orgánica de Partidos Políticos N. ${ }^{\circ} 23.298$.

17 Publicado en el Boletín Oficial del 6/8/2002 (Adla LXII-D-4072). Los Dres. Carlos H. Saravia (apoderado de la Unión Cívica Radical - distrito de la provincia de Salta-) y los Dres. José L. Valle y Luis D. Zavaleta, por sus propios derechos, promovieron acción declarativa de certeza tendiente a hacer cesar el estado de incertidumbre sobre la existencia, alcance y modalidad establecida para las elecciones convocadas por los decretos del Poder Ejecutivo Nacional 1397, 1398, 1399 y 1401, cuya inconstitucionalidad pidieron que se declarara. Manifestaron que el Poder Ejecutivo Nacional, al promulgar la Ley 25.611, modificatoria de la ley orgánica de los partidos políticos 23.298 , se atribuyó la potestad de convocar al electorado para votar en las elecciones abiertas simultáneas y para fijar la fecha en que tendrían lugar los comicios, con lo que - adujeron - quedó habilitado para manejar los tiempos electorales. Asimismo, alegaron que la norma dictada por el Poder 
en la aprobación de las candidaturas y oficializan las boletas de candidatos que se presenten, como así también las boletas electorales a través del órgano que determine sus Cartas Orgánicas, y deben remitir a la Justicia Electoral, para su registración y aprobación definitiva, las boletas partidarias oficializadas. Adviértase que la Justicia Electoral Nacional ${ }^{18}$ interviene en todos los estadios del proceso (cfr. Art. 17, en concordancia con la Ley $N^{\circ} 25.611,23.298$ y Código Electoral Nacional). Los partidos políticos o alianzas que aprueben una sola lista no estarán obligados a hacer elecciones internas en la categoría de la lista (art. 20).

Como se podrá apreciar, los partidos políticos tienen participación necesaria en el proceso electoral y constituyen un instrumento protagonista del sistema democrático. Así los define la Constitución Nacional, en el artículo 38 incorporado en la reforma del año 1994: "Los partidos políticos son institucio-

Ejecutivo violenta lo dispuesto por la ley de internas abiertas votadas por el Congreso de la Nación, ya que ella no permitía que los ciudadanos afiliados a una agrupación partidaria pudieran participar en la elección interna o primera de otra fuerza política. A lo cual debía agregarse la circunstancia de que los padrones que se utilizarian en las elecciones internas abiertas no permiten saber quiénes son afiliados a un partido político y quiénes no registran afiliación, y por lo tanto, son independientes. El tribunal sostuvo que "Con respecto a la convocatoria a elecciones generales no cabe pronunciarse en este proceso, pues si bien la facultad que acuerda el art. 88 de la Constitución Nacional podría ser materia de interpretación acerca de quién debe efectuar la convocatoria, la gravísima crisis constitucional que soporta nuestro pais a partir de los sucesos que se generaron el 20/12/2001, debe llevar a que todos los poderes del Estado actúen con la máxima prudencia y recato, y por consiguiente a no ingresar en cuestiones que puedan afectar el normal funcionamiento de las instituciones, que es lo que a la postre debe preservarse a rajatabla. De manera que la convocatoria a elecciones generales resulta incuestionable judicialmente, razón por la cual el cronograma electoral debe continuar en la forma y modo que lo establecen los decretos correspondientes" (Juzgado Federal de Salta $n .^{\circ} 1$, 23/8/2002, Unión Cívica Radical, Distrito Salta v. Estado Nacional; publicado en Jurisprudencia Argentina, 2002, IV- 500). El pronunciamiento desnuda la gravísima crisis institucional a la que hicimos referencia en el inicio de este trabajo.

${ }^{18}$ La Ley N. ${ }^{\circ} 19.108$ crea una nueva sala en la Cámara Nacional de Apelaciones en lo Federal y Contencioso administrativo de la Capital Federal, que denomina "Sala Electorala, con competencia en todo el territorio de la Nación. La Sala Electoral está compuesta por tres jueces que no deben haber ocupado cargos partidarios hasta 4 años antes de la fecha de su designación. Algunas de sus facultades son: dirigir y fiscalizar el funcionamiento del Registro Nacional de Electores y fiscalizar los de los distritos; dirigir y fiscalizar el funcionamiento del Registro Nacional de Afiliados de los Partidos Políticos; dictar las normas a que deberá sujetare la formación y funcionamiento del los registros generales de distritos, de cartas de ciudadanía, de inhabilitados de faltas electorales; de nombres, símbolos, emblemas y número de identificación de los partidos políticos, y las características uniformes de las fichas de afiliación que llevará y conservará la Justicia Federal Electoral. 
nes fundamentales del sistema democrático. Su creación y el ejercicio de sus actividades son libres dentro del respeto a esta Constitución, la que garantiza su organización y funcionamiento democráticos, la representación de las: minorias, la competencia para la postulación de candidatos a cargos públicos: electivos, el acceso a la información pública y la difusión de sus ideas. El' Estado contribuye al sostenimiento económico de sus actividades y de la capacitación de sus dirigentes. Los partidos políticos deberán dar publicidad del! origen y destino de sus fondos y patrimonios». Esta norma, al mismo tiempo que jerarquiza a los partidos políticos, establece garantías para su creación y funcionamiento; atribuciones, derechos, deberes y dispone, implicitamente, límites a su creación y el consecuente control estatal sobre ello.

Además, los partidos políticos son definidos como «instrumentos: necesarios para la formulación y realización de la política nacional» ${ }^{19}$ y a: ellos "les incumbe, en forma exclusiva, la nominación de candidatos para: cargos públicos electivos" (Ley $N^{\circ} 23.298$, art. $2 .^{\circ}$ ). En otras palabras, el pueblo sólo puede elegir a sus representantes a través de los partidos políticos.

El Decreto $N^{\circ} 1398 / 02^{20}$, del 5/8/2002, fijó el día 24 de noviembre de 2002 para la realización de elecciones abiertas y simultáneas de los candidatos de los partidos políticos o alianzas electorales nacionales a Presidente y Vicepresidente de la Nación para el periodo 2003-2007, convocando a tal fin al electorado de la Nación Argentina.

El Decreto N. ${ }^{\circ} 1579 / 02^{21}$, del 27/8/2002, modifica el Decreto N. ${ }^{\circ} 1398 / 02$, argumentado el Poder Ejecutivo Nacional que, por objeciones de partidos $y_{\text {, }}$ sectores políticos, el amparo para que ocurran todos a las elecciones internas abiertas simultáneas, y la resolución judicial que suspendió el cronograma electoral, fija la fecha para la realización de tales elecciones para el día 15 de diciembre de 2002, explicitando el derecho a sufragar en las mismas a los propio afiliados $y$ a los ciudadanos que carezcan de afiliación política.

Por su parte, el Decreto $N^{\circ} 1.399 / 02^{22}$, del 5/8/2002 establecía el día 30 de marzo de 2003 para las elecciones de presidente y vicepresidente de la

${ }^{19}$ La Corte Suprema de Justicia de la Nación Argentina ha sostenido que "los partidos son instrumentos de gobierno que tienen como función actuar como intermediarios entre éste y las fuerzas sociales" (CSJN, in re "Partido Obrero», Fallos 315:380) y "que consecuentemente tienen deberes... contribuir a la regularidad funcional del proceso político y eficiencia del sistema electoral» (CSJN, "Unión de Fuerzas Sociales», Fallos 315:71).

20 Publicado en el Boletín Oficial del 6/8/2002 (Adla LXII-D-2002, p. 4075).

21 Publicado en el Boletín Oficial del 28/8/2002 (Adla LXII-D-4099).

22 Publicado en el Boletín Oficial del 6/8/2002 (Adla LXII-D-2002, p. 4075). Posteriormente modificado por el Decreto $n .^{\circ} 2.356 / 02$. 
Nación, para el periodo 2003-2007, y el día 27 de abril de ese año para la eventual segunda vuelta electoral prevista en el artículo 96 de la Constitución Nacional. En lo referente a la oportunidad de la elección, la reforma constitucional de 1994 ha reducido el plazo dentro del cual debe realizarse, de cuatro meses ados meses. El artículo 95 vigente dispone que "La elección se efectuará dentro de los dos meses anteriores a la conclusión del mandato del presidente en ejercicio». El Presidente en ejercicio, Dr. Eduardo Duhalde había enunciado su decisión de renunciar el 25 de mayo de 2003, concluyendo anticipadamente el mandato que debía finalizar el 10 de diciembre de $2003^{23}$.

Posteriormente, mediante el Decreto N. ${ }^{\circ}$ 2.356 ${ }^{24}$, del 19/11/2002, modificatorio del Decreto $\mathrm{N}^{\circ} 1.399 / 02$, se convoca al electorado de la Nación Argentina para elegir Presidente y Vicepresidente de la Nación, Diputados y Senadores Nacionales, fijando la fecha de realización de las elecciones para el día 27 de abril de 2003, y el día 18 de mayo de 2003, para la eventual segunda vuelta electoral prevista en el artículo 96 de la Constitución Nacional. A su turno, el Decreto N. ${ }^{\circ} 1.401 / 02^{25}$, del 5/8/2002 convocó a elecciones de diputados nacionales, y el Decreto $N .^{\circ} 2200 / 02$, del $30 / 10 / 2002$, para senadores nacionales.

Finalmente, el Congreso de la Nación sanciona la Ley $\mathbf{N}^{\circ} \mathbf{2 5 . 6 8 4 ^ { 2 6 }}$, en cumplimiento de lo dispuesto por el art. 75 inc. 21) de la Constitución

23 Gelli comenta que «bajo las prescripciones de la ley 20.972, la Asamblea Legislativa designó presidente de la Nación a Eduardo Duhalde, a fin de que éste completase el periodo presidencial inaugurado el 10 de diciembre de 1999, esto es, hasta el 10 de diciembre de 2003. En su consecuencia, el presidente de la Nación así elegido ostentó un título de jure y una representación legítima en segundo grado - fue designado conforme a la ley de acefalía por quienes fueron, a su vez, elegidos por voto popular - con plazo determinado de finalización, que el designado no podía modificar por sí $y$ ante sí mismo. Sin embargo, el presidente en ejercicio, primero verbalmente $y$ luego mediante el dictado del decreto 1399/02 y su modificatorio 2356/02, convocó a elecciones anticipadas y ¿enunció? Su renuncia para el 25 de mayo de 2003. Esos decretos de insólitos fundamentos y cuestionables disposiciones resultaron inconstitucionales pues ni bajo el artículo 88 de la Constitución Nacional ni conforme a las disposiciones de la ley 20972 podía el presidente adelantar según su particular criterio - tampoco retrasarnada menos que la fecha de elecciones y asunción de la nueva fórmula presidencials (GELLI, María Angélica, Constitución de la Nación Argentina comentada y concordada, 2. ${ }^{\circ}$ edición ampliada y actualizada, Editorial La Ley S.A., Buenos Aires, Argentina, 2003, pág. 671/672).

${ }^{24}$ Publicado en el Boletin Oficial del 20/11/2002 (Adla LXII-E-2002, p. 5171).

25 Publicado en el Boletín Oficial del 5/8/2002 (Adla LXII-D-2002, P. 4077).

26 Publicada en el Boletín Oficial del 3/1/2003. 
Nacional27, convocó a elecciones presidenciales para las mismas fechas dispuestas en el Decreto N. ${ }^{\circ} 2356 / 02$, para el período presidencial del 10 de diciembre de 2003 al 10 de diciembre de $2007^{28}$.

El Ministerio del Interior de la Nación dictó la Resolución N. ${ }^{\circ} 237$, del $23 / 04 / 2003$, mediante la cual fija una suma única de Pesos Cien $(\$ 100)$ en concepto de viático a cada uno de los ciudadanos que, no siendo funcionarios ni empleados públicos nacionales, cumplan funciones como autoridades de mesa en las elecciones de Presidente y Vicepresidente de la Nación, Diputados y Senadores Nacionales a celebrarse el día 27 de abril de 2003 y en la eventual segunda vuelta, el 18 de mayo del mismo año. Recordamos que el Código Electoral Nacional califica como "carga pública» a todas las funciones que atribuye a las autoridades de mesa y establece que "son irrenunciables y serán compensadas en la forma que determine esta ley y su reglamentación ${ }^{29}{ }^{2}$. (Ley N ${ }^{\circ} 19.945$, art. 14).

La resolución antes citada fue dictada en ejercicio de las atribuciones conferidas por la Ley de financiamiento de partidos políticos $n^{\circ} \mathbf{2 5 . 6 0 0}^{30}$, la cual establece que el Ministerio del Interior recibirá el diez por ciento $(10 \%)$ de los fondos asignados en la Ley de Presupuesto General de la Nación al: aporte extraordinario para campañas electorales, para otorgar las compensaciones a las autoridades de mesa previstas en el Código Electoral Nacional y para otorgar el aporte destinado a colaborar con los gastos de impresiónı de las boletas electorales (art. $21,2{ }^{\circ}$ párr.). La medida fue criticada por algu-. nos sectores por considerar que la suma era elevada (se había especulado: con un costo de $\$ 20$. - por cada autoridad de mesa, y no de $\$ 100$. - como:

27 Dispone esta cláusula que: “Corresponde al Congreso: ...21) Admitir o desechar los motivos de dimisión del presidente o vicepresidente de la República; y declarar el caso de proceder a nueva elección".

${ }^{28}$ Esta previsión se formuló en cumplimiento de lo establecido en la disposición transitoria Décima, incorporada con la reforma constitucional de 1994: "El mandato del presidente de la Nación que asuma su cargo el 8 de julio de 1995, se extinguirá el 10 de diciembre de 1999". Esta disposición corresponde al artículo 90 de la Constitución que expresa: "El presidente $y$ el vicepresidente duran en sus funciones el término de cuatro años y podrán ser reelegidos o sucederse recíprocamente por un solo período consecutivo. Si han sido reelectos o se han sucedido reciprocamente no pueden ser elegidos para ninguno de ambos cargos, sino con el intervalo de un periodo». A su turno, el art: 91 reza: "El presidente de la Nación cesa en el poder el mismo día en que expira su período de cuatro años; sin que evento alguno que lo haya interrumpido, pueda ser motivo de que se le complete más tarde».

${ }^{29}$ Ley $19.945 / 83$, art. 14 (texto modificado por la Ley $n .^{\circ} 25.610$ - art. $1 .^{\circ}$, sancionada el $19 / 6 / 2002$ y publicada el $8 / 7 / 2002$ ).

30 Publicada en el Boletín Oficial del 12/6/2002 (Adla LXII-C-2883). 
finalmente se estableció), que no se podría hacer efectivo el pago porque superaba el monto disponible en el fondo asignado a tal fin, $y$ porque se trataba de un anuncio demagógico del presidente Duhalde, que quedaria como deuda del próximo gobierno, teniendo en cuenta que ese dinero no se debía pagar por adelantado, sino con posterioridad a los comicios.

\section{ELECCIONES PRESIDENCIALES: ANTECEDENTES CONSTITUCIONALESY LEGALES.}

La Constitución de la Nación Argentina ${ }^{31}$, en su texto originario de 1853 establecía la elección indirecta, a través de los Colegios Electorales de cada una de las provincias, para la elección de presidente y vicepresidente de la Nación.

La reforma constitucional de 1994 sustituye ese sistema por la elección directa de la fórmula presidencial. Es decir, que suprime los colegios electorales, y la votación no es por candidatos por separado sino por ufórmula" ${ }^{32}$. Es evidente que la elección directa del titular del Poder Ejecutivo y la participación en ella de todo el pueblo de la República ensancha la base democrática en que se apoya la representación del Jefe de Estado.

El artículo 94 de la Constitución Nacional establece que: «El presidente $y$ el vicepresidente de la Nación serán elegidos directamente por el pueblo, en doble vuelta, según lo establece esta Constitución. A este fin el territorio nacional conformará un distrito único".

Se advierte que no se admite la recomposición de fórmulas, pues la intención del constituyente fue otorgar mayor transparencia al proceso electoral, evitando las suspicacias que toda negociación de candidatos provoca.

Como adelantara, en el año 2001 se desató una crisis institucional desencadenada por la renuncia del vicepresidente de la Nación, Dr. Carlos (Chacho) Álvarez, primero, en el año 2000, en una derivación del escánda-

31 En adelante, y en forma indistinta, "Constitución Nacional», "Carta Magna», «texto constitucional», "Ley Fundamental», o "C.N.".

32 El Código Electoral Nacional, en la reforma introducida por la Ley N. ${ }^{\circ} 24.444$, establece que "cada ciudadano sufraga por una fórmula indivisible de candidatos a ambos cargos" (art. 148). Asimismo, dispone que, para la elección de presidente y vicepresidente, debe presentarse la fórmula del caso ante el juez federal con competencia en la Capital Federal, quien debe expedirse dentro de cinco días sobre la calidad de los candidatos. La decisión judicial es apelable ante la Cámara Nacional Electoral, que resuelve en definitiva. 
lo que envuelve al Senado de la Nación por el supuesto pago de coimas a algunos senadores nacionales para la aprobación de la reforma laboral, conforme denunciara el entonces Senador Nacional Antonio Cafiero (Partido Justicialista); y más tarde, por el presidente, Dr. Fernando de la Rúa, el 21 de diciembre de aquel año.

El Presidente de la Nación, Dr. Eduardo Duhalde, fue electo por la Asamblea Legislativa del $1 .^{\circ}$ de enero del año $2002^{33}$, con motivo de haberse producido la situación de acefalia contemplada por el artículo 88 de la Constitución Nacional: «... En caso de destitución, muerte, dimisión o inhabilidad del presidente y vicepresidente de la Nación, el Congreso determinará qué funcionario público ha de desempeñar la Presidencia, hasta que. haya cesado la causa de la inhabilidad o un nuevo presidente sea electo". El Dr. Duhalde debía completar el período presidencial inaugurado por el Dr. Fernando de la Rúa el 10 de diciembre de 1999.

No obstante, anunció públicamente su voluntad de renunciar el 25 de mayo de 2003, debiendo anticipar las elecciones presidenciales. En consecuencia, dictó el Decreto N. ${ }^{\circ} 2356 / 02$, antes referido, que en su artículo 6. ${ }^{\circ}$ dispuso: "Hacer efectiva la presentación de la renuncia en forma indeclinable al cargo de PRESIDENTE de la NACIÓN, el día 25 de mayo de 2003; ante la Asamblea Legislativa que se reunirá para tomar juramento al nuevo PRESIDENTE y VICEPRESIDENTE de la NACIÓN, que resultaren electos en las elecciones del 30 de marzo de 2003, o en su caso, del 27 de abril de 2003, de acuerdo a lo preceptuado en el artículo 93 de la Constitución Nacional').

El 28 de noviembre de 2002, el Congreso de la Nación Argentina sancionó la Ley N. ${ }^{\circ} \mathbf{2 5 . 7 1 6 ^ { 3 4 }}$, que modifica la Ley de Acefalia Presidencial N. ${ }^{\circ}$ 20.972, disponiendo en su artículo $1 .^{\circ}$ que «En caso de acefalía por falta de Presidente y Vicepresidente, el Poder Ejecutivo será desempeñado transitoriamente por: 1) el Presidente Provisorio del Senado de la Nación; 2) Por el Presidente de la Cámara de Diputados de la Nación; y a falta de éstos, por el Presidente de la Corte Suprema de Justicia de la Nación, hasta tanto el Congreso reunido en Asamblea haga la designación a que se refiere el articulo 88 de la Constitución Nacional', y que "en caso de existir Presidente y

${ }^{33}$ La Asamblea Legislativa había elegido anteriormente al entonces Gobernador de la Provincia de San Luis, Dr. Adolfo Rodríguez Saá, para el ejercicio provisional de la Presidencia dela Nación, por un plazo de tres meses y con mandato para convocar a elecciones presidenciales dentro de ese lapso. Transcurrida una semana, y después de nuevos disturbios en el Congreso y especulaciones políticas, Rodríguez Saá enviaba su renuncia desde la Provincia de San Luis.

34 Publicada en el Boletín Oficial del 08/01/2003 Adla LXIII-A-2003, p. 53). 
Vicepresidente de la Nación electos, éstos asumirán los cargos acéfalos", agregando que "el tiempo transcurrido desde la asunción prevista en este artículo hasta la iniciación del período para el que hayan sido electos, no será considerado a los efectos de la prohibición prevista en el último párrafo del artículo 90 de la Constitución Nacionalı ${ }^{35}$.

\section{REFORMA CONSTITUCIONAL DE 1994: SEGUNDA VUELTA ELECTORAL.}

Como anticipara, la República Argentina reformó el texto de su Constitución Nacional en el año 1994, modificando el sistema de elección de los integrantes de la fórmula presidencial. Este procedimiento ya había sido adoptado con anterioridad por la República Argentina, en las elecciones presidenciales ocurridas en el año $1973^{36}$.

Gelli, con acierto, opina que "las enmiendas referidas a la forma y tiempo de elección del presidente y vicepresidente de la Nación incremen-

35 El artículo 90 de la Constitución de la Nación Argentina establece: “El presidente $y$ vicepresidente duran en sus funciones el término de cuatro años y podrán ser reelegidos o sucederse reciprocamente por un solo período consecutivo. Si han sido reelectos o se han sucedido recíprocamente no pueden ser elegidos para ninguno de ambos cargos, sino con el intervalo de un periodo". Por tal motivo, opina Gelli que la Ley 25.716 «tuvo nombre y apellido. En efecto, dado que uno de los precandidatos por el Partido Justicialista era el ex presidente Carlos Menem, la iniciación del nuevo periodo presidencial el 25 de mayo de 2003, podía llevar a impugnar su candidatura, pues por aplicación del art. 90, estrictamente, estaría imposibilitado de acceder a un nuevo mandato presidencial» (GeLLI, María Angélica, op.cit., pág. 672).

${ }^{36}$ El 28 de junio de 1966 las Fuerzas Armadas depusieron al presidente Dr. Arturo Illia, asumiendo la presidencia de la Nación el Teniente General Dr. Juan Carlos Onganía. Posteriormente, la Junta de Comandantes en Jefe, ejerciendo la presidencia de la Nación el general Alejandro A. Lanusse, dictó el 24 de agosto de 1972 un Estatuto Fundamental que reformaba algunos artículos de la Constitución Nacional. El artículo 81 establecía que el presidente y vicepresidente fueran elegidos simultánea y directamente por el pueblo de la Nación, cuyo territorio, a ese efecto, formaba un distrito único; y además introduce el para el caso que los candidatos no obtuvieran más del cincuenta por ciento $(50 \%)$ de los votos válidamente emitidos. En las elecciones celebradas el 11 de marzo de 1973, la fórmula del Partido Justicialista integrada por el Dr. Héctor J. Cámpora (presidente) y el Dr. Vicente Solano Lima (vicepresidente), no logró ese porcentaje por escaso margen, pues obtuvo el $49,59 \%$. La fórmula opositora del radicalismo, que seguia en número de sufragios, formada por Ricardo Balbín y Eduardo Gamond, distaba de aquel porcentaje, alcanzando sólo el 21,30\% del electorado, razón por la cual renunció a la presentación en segunda vuelta, proclamándose aquélla ganadora. 
taron los componentes democráticos de ese sufragio popular ${ }^{37} \mathrm{y}$ atenuaron el peso de las provincias de la designación de la primera magistratura del país (.....) Por cierto con el cambio instrumentado en 1994, pocos distritos electorales son los que deciden, en los hechos, la suerte de la elección presidencial. Pero el procedimiento es indudablemente mucho más democrático que el anterior» ${ }^{38}$.

Y es evidente, a juzgar por la composición demográfica de nuestra Nación, que de los veinticuatro distritos electorales (23 provincias y la Capital Federal), dos territorios son los que gravitan decisivamente en el resultado de las elecciones presidenciales; me refiero a la Provincia de Buenos Aires $(37,3 \%$ ) y a la Capital Federal $(10,3 \%)$, que reúnen el $47,6 \%$ del total del electorado de la Nación Argentina ${ }^{39}$.

A su turno, el artículo 96 de la Carta Magna consagra que "La segunda vuelta electoral, si correspondiere, se realizará entre las dos fórmulas de candidatos más votadas, dentro de los treinta días de celebrada la anterior». Por tal motivo, el Decreto 2.356/03 estableció el 27 de abril de 2003 para la primera votación, y el 18 de mayo del mismo año para la segunda vuelta.

Quiroga Lavié advierte en su comentario a esta disposición, que: "La primera observación que surge de esta cláusula, a partir de la cual la Constitución comienza a procedimentar el balotaje a la argentina, es que la segunda vuelta electoral se hará solamente entre las dos fórmulas más votadas; ello significa que la constitución no permite la reconstitución de fórmulas. Recordamos aquí que, en el trámite político que llevó a la reforma, se pronunció a favor del balotaje (claro que por el 50\%) el Consejo de Consolidación de la Democracia, de orientación radical, en tanto que el justicialismo, antes del Pacto de Olivos, había manifestado disconformidad con este modo de elección. Al acuerdo se llegó a partir de renuncias mutuas: el justicialismo tuvo que aceptar el balotaje, $y$ el radicalismo, a su turno, la reelección presidencial» ${ }^{40}$.

37 Quiroga Lavié, en opinión coincidente, expresa que «el balotaje: constitucionalizado en la Argentina implica también, así como ocurrió con el establecimiento de la elección directa, una reforma dirigida a robustecer el sistema. democrático, toda vez que el nuevo presidente deberá ser elegido por una mayoria substancial de votos, y no por una mayoría simple, como ocurriría si no se apelara a esta variable electoral» (QUIROGA LAVIE, Humberto, Constitución de la Nación Argentina comentada, $2 .^{\circ}$ edición actualizada, Zavalia Editor, Buenos Aires, Argentina, 1997, pág. 574).

38 GelLI, María Angélica, op.cit., pág. 683.

${ }^{39}$ Se puede consultar el trabajo del Dr. Sergio Díaz Ricci, «Pérdida de las provincias por la votación directa del Presidenten, publicado en la revista Debates de actualidad, Asociación Argentina de Derecho Constitucional, Año XVIII - N. ${ }^{\circ} 191$, julio-octubre de 2003, Rubinzal - Culzoni Editores, Santa Fe, Argentina, 2003, págs. 56/68.

40 Quiroga LaVíe, Humberto, op.cit.5, pág. 574. 
A pesar de que el texto constitucional adopta literalmente la terminología "segunda vuelta electoral», es usual y extendida la alusión al "ballottage», como en el derecho electoral francés, y menos frecuente el vocablo "balotaje». De todos modos, cualesquiera sea la denominación y más allá del rigor técnico, en forma unívoca se refieren a la nueva votación que, en los comicios electorales, se celebra tras un lapso breve, cuando en el primer escrutinio ningún candidato, lista o fórmula ha obtenido la mayoría absoluta de votantes o de electores. Este sistema tiende a permitir al electorado modificar su voto en un acto posterior y optar entre los más votados, atribuyendo el triunfo al más votado - aunque no se produzca la mayoria absoluta-, a fin de no cansar al cuerpo electoral con una reiteración indefinida. Recordamos que el "ballottage" (votar con bolillas) nació en Francia en 1852, cuando el emperador Napoleón III lo instaló para una elección legislativa, y luego de algunas intermitencias, fue reeditado en 1965 para los comicios presidenciales que dieron el triunfo a Charles De Gaulle, quien venció en segunda vuelta a François Miterrand, que había ganado en primera vuelta. En la Argentina, debutó el 11 de marzo de 1973, producto de una enmienda constitucional. El actual balotaje presidencial es el resultado del Pacto de Olivos (suscripto entre el entonces Presidente de la Nación, Carlos Saúl Menem y el Presidente de la Unión Cívica Radical y ex presidente, Dr. Raúl Ricardo Alfonsín, en noviembre de 1993 ${ }^{41}$, y su inclusión en la Ley N. ${ }^{\circ} 24.309^{42}$, que declaró la necesidad de la reforma constitucional de 1994 y los puntos de la reforma (Núcleo de Coincidencias Básicas, punto E).

En la Convención Nacional Constituyente de 1994, el Dr. Alfonsín expuso: «El ballottage sirve a dos propósitos: en primer lugar, es útil para desempatar preferencias politicas muy parejas, cuando ninguna de ellas alcanza la mayoría absoluta de los votos emitidos. En segundo lugar, permite que la ciudadanía exprese sus preferencias negativas respecto de algún candidato y que se formen amplias coaliciones, asegurando a un grupo importante de electores, la elección del «segundo mejor» cuando su candidato pierda en la primera vuelta. La segun-

41 El ex presidente Alfonsín (Unión Cívica Radical) impuso la doble vuelta como una de las monedas de cambio para habilitar la reelección del entonces presidente Carlos Menem (Partido Justicialista). Y el Partido Justicialista (P.J.) que, en principio, rechazaba la aplicación del sistema, aceptó su implementación. Incorporada con la reforma constitucional de 1994, comenzó a regir por primera vez en las elecciones presidenciales de 1995, aunque no se aplicó porque la fórmula Menem-Ruckauf (P.J.) obtuvo el $49,8 \%$ de los votos en primera vuelta derrotando Al candidato del Frepaso, José Bordón. Cuatro años más tarde, Fernando de la Rúa-Chacho Álvarez venció en primera vuelta, con el $48,4 \%$ de los sufragios, a Eduardo Duhalde, que obtuvo el $38,3 \%$, situación que tornó innecesaria la segunda vuelta electoral.

42 Sancionada y promulgada el 29 de diciembre de 2003. 
da vuelta opera como un incentivo cooperativo entre las distintas fuerzas políticas, sobre todo para las mayoritarias, quienes deberán asumir compromisos con las minorías políticas afines, con el objeto de lograr consensos más amplios. En otras palabras, la llegada del poder presidencial implicaria negociar el progreso del gobierno con grupos políticos más reducidos, en ocasiones incorporándolos al gabinete o formando con ellos una coalición mayoritariamente capaz de sostener al jefe de gabinete que elija el Presidente ${ }^{43}$.

La Carta Magna de la República Argentina prevé dos casos de proclamación automática, que no requieren de una segunda vuelta electoral. El primer supuesto está contemplado en el artículo 97: "Cuando la fórmula que resultare más votada en la primera vuelta, hubiere obtenido más del cuarenta y cinco por ciento de los votos afirmativos válidamente emitidos, sus integrantes serán proclamados como presidente y vicepresidente de la Nación".

La segunda alternativa que prescinde de la segunda vuelta es la que establece el artículo 98: "Cuando la fórmula que resultare más votada en la primera vuelta hubiere obtenido el cuarenta por ciento por lo menos de los votos afirmativos válidamente emitidos $y$, además, existiere una diferencia mayor de diez puntos porcentuales respecto del total de los votos afirmativos válidamente emitidos sobre la fórmula que le sigue en número de votos, sus integrantes serán proclamados como presidente y vicepresidente de la Nación". La regla se apartó de su antecedente francés, donde se obtiene dicho derecho (a ganar las elecciones) siempre que la fórmula ganadora logre el $50 \%$ de los votos.

Sobre un total de $\mathbf{2 5 . 4 8 0 . 4 4 0 ~ e l e c t o r e s ~ h a ́ b i l e s , ~ v o t o ́ ~ e l ~ s e t e n t a ~ y ~ o c h o ~}$ por ciento $(78,22 \%)$, es decir, 19.9310.111. Del total de sufragantes, resultaron $19.387 .895(97,38 \%)$ votos positivos; $196.574(0,99 \%)$ votos en blanco; y $345.642(1,73 \%)$ votos nulos.

Los resultados electorales obtenidos en la primera vuelta no permitieron consagrar de inmediato una fórmula vencedora. Separadas por un estrecho margen de sufragios, las dos fórmulas más votadas fueron los binomios integrados por Carlos Saúl Menem-Juan Carlos Romero (Partido Justicialista), que obtuvo el 24,45 \% de los votos; y Néstor Kirchner-Daniel Scioli, (Partido Justicialista), que logró $22,24 \%{ }^{44}$. Por tal motivo, era necesario ocurrir a la segunda vuelta electoral prevista para el día 18 de mayo de 2003, aunque un hecho político varió el desenlace.

43 Convención Nacional Constituyente, Diario de Sesiones, inserción n. ${ }^{\circ} 2, p$. 2733, discurso de Dr. Raúl Ricardo Alfonsin (citado por Dromi-Menem, op.cit., p. 316).

44 El peronismo ha sido otra vez el gran protagonista de la jornada electoral. Los resultados indican que, sumados sus tres candidatos, alcanzaron el 60 por ciento de los 
Para proporcionar una visión integral, se reflejan los resultados del escrutinio definitivo:

\begin{tabular}{lccc} 
FÓRMULAS PRESIDENCIALES & PARTIDO & VOTOS & PORCENTAJE (\%) \\
\hline MENEM-ROMERO & Justicialista (1) & $\mathbf{4 . 7 4 0 . 9 0 7}$ & 24,45 \\
\hline KIRCHNER-SCIOLI & Justicialista (2) & 4.312 .517 & 22,24 \\
\hline LOPEZ MURPHY - GOMEZ DIEZ & A.Mov.p/Recrear & 3.173 .475 & 16,37 \\
\hline RODRIGUUEZ SAÁ - POSSE & Justicialista (3) & 2.735 .829 & 14,11 \\
\hline CARRIÓ - GUTIÉRREZ & A.R.I. & 2.723 .574 & 14,05 \\
\hline MOREAU - LOSADA & U.C.R. & 453.360 & 2,34 \\
\hline WALSH - PARRILLI & Alianza lzquirda Unida & 332.863 & 1,72 \\
\hline BRAVO - GIUSTINIANI & Socialista & 217.385 & 1,12 \\
\hline ALTAMIRA - SALAS & Obrero & 139.399 & 0,72 \\
\hline VENTURINI - PINTO KRAMER & Cont.P/que se vayan todos & 129.764 & 0,67 \\
\hline SULLINGS - AMBROSIO & Humanista & 105.702 & 0,55 \\
\hline ARCAGNI - ZENOF & Unión Popular & 63.449 & 0,33 \\
\hline MAZZITELLI - CAMPS & Socialista Auténtico & 52.239 & 0,26 \\
\hline HERRERA - CÚNEO & Democracia Cristiana & 47.750 & 0,25 \\
\hline ZAFFORE - PERIÉ & M.I.D. & 47.951 & 0,25 \\
\hline BREIDE OBEID - VASENA & Popular de la Reconstrucción & 42.460 & 0,22 \\
\hline MUSSA - SUÁREZ & Al. Unidos o Dominados & 39.505 & 0,20 \\
\hline TERÁN - BONACCI & MODIN & 31.766 & 0,16 \\
\hline
\end{tabular}

Referencias:

(1) Frente por la Lealtad / U.C.D. (Unión de Centro Democrático)

(2) Frente para la Victoria

(3) Alianza Movimiento Frente Popular / Unión y Libertad

votos emitidos, apenas por debajo de su registro histórico, con Perón en vida, en 1973. Esto apenas si dice algo sobre una de las incógnitas que seguirán a la segunda ronda electoral: si el justicialismo recuperará su unidad de acción, cualquiera que sea el próximo presidente. El peronismo puso ayer en juego su jefatura, una definición que ha sido postergada hasta la segunda ronda electoral. Pero la consolidación de un polo de poder, ya sea el de Menem o el de Kirchner, no necesariamente reproducirá un liderazgo único, como ha sido tradición del principal actor político del país. Una primera lectura indica que Menem ganó la interna entre los tres candidatos justicialistas, una elección que se le negó en febrero pasado. Sin embargo, todavía no es posible determinar la incidencia en ese resultado del voto independiente, $o$ al menos no peronista, tanto en los números de Menem como de Kirchner. Parece en cambio más claro que las opciones por Kirchner, Menem y Rodríguez Saá provienen de cortes sociales distintos, un dato que se ve mejor en la procedencia geográfica de sus votos. Mientras el de Kirchner representa una opción preferentemente urbana (ganó en Buenos Aires, Formosa, Jujuy y la Patagonia); Menem hace su mejor elección en ciudades chicas (Noroeste y Nordeste), y Saá es un fenómeno exclusivamente regional (Cuyo)" (Diario Clarín, Política, Buenos Aires, República Argentina, 28 de abril de 2003, pág. 2). 
La Justicia Nacional Electoral finalizó el escrutinio definitivo, sin que ningún partido o alianza electoral formalizara ninguna impugnación al resultado de la primera vuelta, a pesar de las denuncias públicas (en los medios) de fraude por parte de las otros candidatos que participaron en la contienda. Los resultados finales de las veinticuatro (24) juntas electorales del país fueron enviados a la Cámara Nacional Electoral y posteriormente remitidos al Senado, cuyo Presidente provisional convocó a Asamblea Legislativa. La Asamblea Legislativa dio a conocer el resultado definitivo del escrutinio de todo el país y oficializó a las fórmulas de Menem-Romero y Kirchner-Scioli para participar en la segunda vuelta electoral prevista para el 18 de mayo de 2003.

\section{CRÓNICA DE UN RESULTADO ANUNCIADO: RENUNCIAY PROCLAMACIÓN.}

Finalmente, tal como anunciaron las crónicas más arriesgadas y las consultoras certeras, la fórmula presidencial integrada por Carlos Saúl Menem y Juan Carlos Romero, no obstante haber obtenido el primer lugar en el escrutinio, el 14 de mayo de 2003, presentó su renuncia a la segunda vuelta electoral, produciéndose la proclamación automática de la fórmula encabezada por Néstor Kirchner y secundada por Daniel Scioli. Transcribo el texto de la renuncia ${ }^{45}$ con la intención de ofrecer al lector una mayor aproximación a los hechos suscitados en esos días:

45 La autora agradece al Sr. Presidente de la Junta Electoral Nacional y de la Cámara de Apelaciones en lo Contencioso Administrativo Federal, Dr. Pablo Oscar Gallegos Fedriani, el generoso aporte de tan valioso material. 
HACEN SABER.

\section{Excelentísima}

Junta Electoral Nacional

De la Capital Federal:

Carlos Saúl Menem y Juan Carlos Romero, manteniendo el domicilio constituido en autos, con el patrocinio letrado del Dr. Luis Rodolfo Giacosa, a esa Excelentísima Junta Electoral Nacional se presentan y dicen:

Que vienen a comunicar su formal desistimiento de la voluntad de participar en la segunda vuelta de las elecciones convocadas para Presidente y Vicepresidente de la Nación, por lo que piden se tengan por renunciadas sus candidaturas y se proceda conforme a derecho.

Tan grave determinación ha sido tomada en serena reflexión y pesando todas las razones en pro $y$ en contra de una actitud política de tan significativa importancia en la vida institucional de la Nación.

La consideración central y dirimente tiene que ver con la antinomia instalada en la sociedad en una perversa divisoria de aguas entre menemistas $y$ antimenemistas.

Los comparecientes creen que esa alternativa impugna de ilegitimidad a cualquier resultado electoral que cabalgue sobre ella, porque el poder que surja ungido por el comicio no podrá considerarse como un mandato en torno a un programa y a una propuesta de acción para enfrentar la crisis argentina, sino tan solo como una gigantesca encuesta de opinión sobre un candidato singular.

Los resultados del 27 de abril, donde el electorado tuvo a su disposición una variada propuesta, constituyen una clara expresión de la realidad política, de las inclinaciones y orientaciones del pueblo argentino.

Con ese caudal electoral, cada partido, cada dirigente, cada candidato debe sostener su propuesta y su accionar. No seria legítimo pedir a las víctimas de una demonización mediática sin precedentes que convaliden con su participación la creación de una imagen de consenso ficticio, unido tan solo por el antagonismo y el rechazo.

Esclavos de la ley, como somos los hombres libres, consentimos en que se proclame electa la fórmula que compartió con nosotros el derecho a participar en la segunda vuelta.

SERÁ JUSTICIA.

(Firman los presentantes: Carlos S. Menem, Juan Carlos Romero, y Luis Giacosa -apoderado de la lista del Frente por la Lealtad-) 
Presentada la renuncia, la Junta Nacional Electoral procedió de inmediato a su aceptación y la proclamación de la fórmula integrada por Néstor Kirchner y Daniel Scioli, para su posterior elevación al Senado por la Cámara Nacional Electoral. El 25 de mayo de 2003, ante la Asamblea Legislativa, presidida por el senador José Luis Gioja (P.J. - San Juan) y el diputado Eduardo Camaño (P.J. - Buenos Aires), el presidente electo asumió en el Congreso de la Nación ante la presencia de doce presidentes de América Latina ${ }^{46}$. En un recinto colmado de legisladores, gobernadores de provincia, funcionarios, eclesiásticos, diplomáticos $\mathrm{y}$ jefes de Estado extranjeros, se cumplió el traspaso del mando presidencial. El presidente saliente, Eduardo Duhalde, hizo entrega de la banda y el bastón de mando al nuevo presidente constitucional, Néstor Kirchner. El flamante mandatario pronunció su primer discurso ante la Asamblea Legislativa: «Vengo a proponerles un sueño: reconstruir nuestra propia identidad como pueblo y como Nación». En un pasaje posterior, proclamó un fuerte mensaje de cambio: "Concluye una forma de hacer política en Argentina".

La ceremonia culminó en el Salón Blanco de la Casa Rosada, con el juramento del Jefe de Gabinete de Ministros (Alberto Fernández); de los ministros de Economía (Roberto Lavagna); de Interior (Aníbal Fernández); de Relaciones Exteriores (canciller Rafael Bielsa); de Defensa (José Pampurro); de Justicia (Gustavo Béliz); de Planificación Federal (Julio de Vido); de Trabajo (Carlos Tomada); de Educación (Daniel Filmus); de Desarrollo Social (Alicia Kirchner); de Salud (Ginés González García); y de los tres Secretarios de Estado: Secretaria General de la Presidencia (Oscar Parrilli); Secretaría Legal y Técnica (Carlos Zannini); Secretaría de Cultura (Torcuato Di Tella) y Secretaría de Inteligencia del Estado - SIDE - (Sergio Acevedo).

A partir del 10 de diciembre de 2003, la gestión presidencial adquiere una particularidad: mayoría propia en ambas Cámaras del Congreso. Por supuesto que la mayoría parlamentaria oficialista no garantiza al Jefe de Estado una alineación automática de todos sus miembros pero, es probable que ello facilite un respaldo a su política de gobierno.

${ }^{46}$ Estuvieron presentes en el acto de asunción, el príncipe de España, Dn. Felipe. de Borbón; los presidentes de Brasil (Luiz Inacio Lula Da Silva); de Chile (Ricardo Lagos); de Uruguay (Jorge Batlle); de Paraguay (Luis González Macchi); de Bolivia (Gonzalo, Sánchez de Lozada); de Perú (Alejandro Toledo); de Colombia (Alvaro Uribe); de: Venezuela (Hugo Chávez); de Ecuador (Lucio Gutiérrez); de Guatemala (Alfonso Portillo); de Panamá (Mireya Moscoso); y de Cuba (Fidel Castro). 


\section{PRINCIPALES MEDIDAS DURANTE EL PRIMER AÑO DE GOBIERNO.}

No es tarea simple seleccionar las principales acciones de gobierno, sobre todo cuando las cuestiones económico - financieras centran toda la atención en ese foco. No obstante esta digresión, y tomando en consideración la gravitación que tienen las vinculaciones entre los órganos del Estado, a las que habíamos hecho referencia, me permito seleccionar dos medidas que particularmente estimo de gran trascendencia en la vida político institucional de la República Argentina, que se relacionan una con el Poder Judicial, y la otra con el Poder Legislativo.

\section{a) Acerca de la designación de los magistrados de la Corte Suprema de Justicia de la Nación.}

En su discurso de asunción, el presidente Kirchner había anunciado «su compromiso reiterado con el mejoramiento de la calidad institucional", y dejó abierto dos frentes: uno, el de las Fuerzas Armadas; el otro, el de la Justicia.

Poco después, el 19 de junio de 2.003, el Poder Ejecutivo Nacional dictó el Decreto $\mathbf{N}^{\circ}{ }^{222}{ }^{47}$, que reglamenta el ejercicio de la atribución presidencial para el nombramiento de los magistrados de la Corte Suprema de Justicia de la Nación (art. 99 inc. 4 C.N.).

El artículo 99 de la Constitución Nacional establece: «El Presidente de la Nación tiene las siguientes atribuciones: [...] 4. Nombra los magistrados de la Corte Suprema con acuerdo del Senado por dos tercios de sus miembros presentes, en sesión pública ${ }^{48}$, convocada al efecto [...]».

La cláusula transcripta regula una de las atribuciones institucionales más importantes del presidente de la Nación. Mediante la designación de los miembros de la Corte Suprema de Justicia de la Nación, en un caso, y en otro, de los jueces federales, de entre la terna que le presenta el Consejo de la Magistratura, el presidente participa en la conformación de uno de los poderes del Estado, el que resulta más significativo en la defensa de los derechos y garantías de las personas, y el que tiene a su cargo el control de los excesos del poder, dando curso a la inconstitucionalidad de normas, actos y omisiones estatales ${ }^{49}$.

47 Decreto N. ${ }^{\circ} 222 / 2003$ publicado en el Boletín Oficial del 20/6/2003.

48 Antes de la reforma constitucional de 1994, el acuerdo se prestaba en sesión secreta. La modificación tuvo por finalidad otorgar mayor transparencia y publicidad a la designación de los magistrados $y$, de ese modo, desalentar viciosas prácticas políticas en la distribución de cargos de tan alta envergadura.

49 Gelli, ... op.cit., pág. 709. 
Obvio resulta que la atribución presidencial se preserva intacta; es una facultad esencialmente política, exclusiva e indelegable ${ }^{50} \mathrm{y}$, como tal puede reglamentarla. El presidente puede ejercerla bajo parámetros discrecionales en la apreciación de las calidades jurídicas y la cosmovisión que el candidato sustenta acerca de las políticas globales $-y$ no partidarias - requeridas para el cumplimiento cabal de la Constitución Nacional, desde que este máximo Tribunal es su custodio e intérprete final.

Los considerandos del mencionado Decreto reglamentario expresan:

- Que es pertinente que el ejercicio de esta facultad por parte del Poder Ejecutivo Nacional sea reglamentada estableciendo parámetros a tener en cuenta para mejor selección del candidato propuesto de modo que su designación contribuya de cierto modo en aporte a un efectivo mejoramiento del servicio de justicia, cuya garantía debe el Estado proveer a los ciudadanos, al fortalecimiento del sistema republicano $y$ al incremento de la calidad institucional.

- Que resulta necesario tener presente, a la hora del ejercicio de tal facultad, las circunstancias atinentes a la composición general del Alto Cuerpo en cuanto a diversidad de género, especialidades profesionales, e integración con un sentido regional $y$ federal.

- Que a ello deben sumarse los requisitos relativos a la integridad moral e idoneidad técnica y el compromiso con la democracia y la defensa de los derechos humanos que el o los postulantes deben reunir.

- Que para mejor cumplimiento de las finalidades indicadas resulta conveniente posibilitar, con la conformidad expresa de quien o quienes resulten motivo de solicitud de acuerdo, la acreditación de aspectos relativos a su trayectoria personal y académica, los compromisos públicos y privados que tuvieren, la concurrencia de los requisitos establecidos en la Ley de Ética de la Función Pública, y del cumplimiento de sus respectivas obligaciones impositivas.

- Que corresponde, también, crear los mecanismos que permitan a los ciudadanos, individual o colectivamente, a los colegios y a las

50 La Corte Suprema de Justicia de la Nación ha establecido que "lo atinente a las calidades de los magistrados para el desempeño de su ministerio es, como principio, cuestión que incumbe a los poderes públicos y no es debatible en juicion (Fallos 240:429; 244:450). 
asociaciones que agrupan a sectores del ámbito profesional, académico o científico de que se trata, a las no gubernamentales con interés $y$ acciones en el tema, hacer conocer en forma oportuna sus razones, puntos de vista y objeciones que pudieran tener respecto del nombramiento a producir.

- Que resulta conveniente adoptar un procedimiento que ordene y acote en un tiempo prudencial el ejercicio de los derechos de participación de los ciudadanos en el manejo de las cuestiones públicas de interés que esta reglamentación busca instrumentar.

- Que el procedimiento así reglado y los dispositivos del presente se adoptan sin perjuicio de la competencia y los procedimientos establecidos por el Honorable Senado de la Nación en virtud de la atribución que el artículo constitucional citado le confiere y su propio reglamento determine.

La finalidad última de los procedimientos adoptados es la preselección de candidatos para la cobertura de vacantes en la Corte Suprema de Justicia de la Nación en un marco de prudencial respeto al buen nombre $y$ honor de los propuestos, la correcta valoración de sus aptitudes morales, su idoneidad ${ }^{51}$ técnica y jurídica, su trayectoria y su compromiso con la defensa de los derechos humanos y los valores democráticos que lo hagan merecedor de tan importante función (art. 1. ${ }^{\circ}$ Dec. 222).

El procedimiento establecido puede sintetizarse en cuatro etapas:

1. De postulación:

Producida la vacante, en un plazo máximo de treinta (30) días se publica en el Boletín Oficial y en por los menos dos (2) diarios de circulación nacional, durante tres (3) días, el nombre y los antecedentes curriculares de la o las personas propuestas para la cobertura del cargo vacante. Asimismo, se difundirá en la página oficial de la red informática del Ministerio de Justicia, Seguridad y Derechos Humanos.

\section{De consulta:}

Las personas propuestas deben presentar una declaración jurada de bienes en las condiciones que establece el art. 6 de la Ley de Ética de la Función Pública N. ${ }^{\circ}$ 25.188; la nomina de asociaciones civiles y sociedades comerciales que integren o hayan integrado en los últimos ocho (8) años, los

$51 \mathrm{El}$ art. 16 de la Constitución Nacional establece que "[...] Todos sus habitantes son iguales ante la ley, y admisibles en los empleos públicos sin otra condición que la idoneidad [...]». 
estudios de abogados a los que pertenecieron o pertenecen; la nómina de clientes y contratistas de por lo menos los últimos ocho (8) años; y en general, cualquier tipo de compromiso que pueda afectar la imparcialidad de su criterio por actividades propias, con la finalidad de permitir la evaluación objetiva de la existencia de incompatibilidades o conflictos de intereses.

3. De impugnación:

Los ciudadanos, organizaciones no gubernamentales, colegios y asociaciones profesionales, entidades académicas $y$ de derechos humanos, podrán en el plazo de quince (15) días a contar desde la última publicación en el Boletín Oficial, presentar por escrito y en forma fundada y documentada, ante el Ministerio de Justicia, Seguridad y Derechos Humanos, las posturas, observaciones y circunstancias que consideren de interés respecto de los incluidos en el proceso de preselección. El Poder Ejecutivo requiere a la Administración Federal de Ingresos Públicos (AFIP) informe relativo al cumplimiento de las obligaciones fiscales de los propuestos.

\section{Decisoria o de nombramiento:}

En un plazo que no deberá superar los quince dias a contar desde el vencimiento del establecido para la presentación de las posturas $u$ observaciones, el Poder Ejecutivo Nacional dispondrá sobre la elevación o no de la propuesta respectiva. En caso de decisión positiva, se enviará con lo actuado al Honorable Senado de la Nación el nombramiento respectivo, a los fines del acuerdo.

La Corte Suprema de Justicia de la Nación está integrada por nueve miembros ${ }^{52}$, de los cuales tres fueron nombrados por el ex presidente Raúl Alfonsín; cinco, durante la presidencia de Carlos Menem; y uno, el último en ingresar en la Corte ${ }^{53}$ antes de la asunción de Kirchner, por el presidente saliente Eduardo Duhalde.

52 El número de integrantes de la Corte Suprema de Justicia no está regulado por la Constitución Nacional sino que ésta lo ha deferido a la decisión del Congreso. De esta manera, la composición de la Corte ha ido variando. La Ley $\mathrm{N}^{\circ}{ }^{\circ} 27$, del año 1862, estableció una Corte de cinco ministros; la Ley $N^{\circ} 15.271$, del año 1959, amplió ese número a siete; en el año 1966, la Ley $\mathrm{N} .^{\circ} 16.895$ retornó a cinco miembros, composición que se mantuvo hasta 1990, en el cual -durante la presidencia de Carlos Menem - se amplió a nueve integrantes por medio de la Ley $\mathrm{N} .^{\circ} 23.774$, a pesar de la opinión crítica que recibió ese proyecto de Ley de parte de la Corte de Justicia, que puso en conocimiento del Poder Legislativo y del Poder Ejecutivo, su disconformidad con la ampliación del número de integrantes de ese Tribunal, mediante Acordada $n .^{\circ} 44 / 89$.

53 Nos referimos al Dr. Juan Carlos Maqueda, que asumió en reemplazo del Dr. Gustavo Bossert, quien habia renunciado ante el desprestigio social motivado por las manifestaciones populares en disconformidad con el rol de la Corte (reclamaban "que 
Desde la asunción del presidente Kirchner, renunciaron los magistrados de la Corte, Dres. Julio Nazareno y Guillermo López ${ }^{54}$-en pleno proceso de juicio político - y fue destituido, mediante ese mecanismo constitucional, el juez de la Corte, Dr. Eduardo Moliné O'Connor.

se vayan todos") y las presiones, por parte del Poder Ejecutivo, con la promoción de un juicio político a todos los integrantes de la Corte.

54 El juicio político fue el desencadenante de las sucesivas renuncias: Julio Nazareno renunció en junio de 2003; luego Guillermo López, en octubre del mismo año. Por su parte, el magistrado de la Corte, Dr. Carlos S. Fayt. debió enfrentar tres pedidos de juicio político en la Cámara de Diputados de la Nación. El 29 de abril de 2003 presentó su descargo ante la Comisión de Juicio Político de esa Cámara, declarando que no renunciaria a su cargo "aunque avance el pedido de juicio político en el Congreso, porque no tiene ningún fundamento para suspenderlo o destituirlo". Los medios de difusión especulaban que "No es un secreto que el gobierno de Néstor Kirchner pretende cuanto antes oxigenar la Corte y neutralizar la llamada "mayoría automática» de sus miembros, a los que considera afines al menemismo. La decisión de acelerar el enjuiciamiento a Fayt es un síntoma claro de esa decisión; si bien el juez no integra esa mayoría automática, el gobierno imagina que su eventual destitución del cuerpo originaría un efecto dominó entre sus pares, que buscarían su retiro" (Diario La Nación, Buenos Aires, República Argentina, 29/5/2003, pág. 7).

En el último año de la presidencia de Duhalde, se habia promovido juicio político contra los nueve magistrados de la Corte Suprema, que no prosperó al no lograr la mayoría de dos tercios de los miembros de la Cámara de Diputados que se requiere para la acusación. "Se trata de una mayoría difícil de conseguir si previamente no se teje un amplio acuerdo en la Cámara Baja. De hecho, en octubre último (2002), los diputados opositores (al P.J.) y un puñado de justicialistas fracasaron en su intento de enjuiciar a los nueve miembros del alto tribunal, también por mal desempeño en sus funciones. En aquella oportunidad, fue el propio bloque del P.J. el que boicoteó el proceso, a pesar de que lo avaló en un principio. $E$ entonces gobierno de Eduardo Duhalde temía que la Corte emitiera fallos que desestabilizaran su frágil política económican (Diario La Nación, Buenos Aires, República Argentina, 28/5/2003, pág. 7).

En una entrevista con un diario de circulación nacional, el Dr. Rafael Bielsa (Síndico General de la Nación durante el gobierno de De la Rúa, y luego designado canciller por el presidente Kirchner) dijo: "Con respecto a la Corte Suprema, creo en una relación de comunicación sin cohabitación. En toda la maquinaria de remoción de un juez de la Corte, el Poder Ejecutivo no tiene nada que hacer; la acusación es un resorte de una de las cámaras del Congreso (Diputados) y el juicio de la otra (Senado). Tampoco me parece bien como gobierno confrontar públicamente en función del contenido de los fallos; no puede ser que cuando la Justicia nos favorezca sea considerada correcta, y cuando nos perjudique, sea menemista o adicta. [...] Así como fue malo diez años atrás que en cinco minutos $\mathbf{4 5}$ segundos se votara la ley de ampliación de miembros de la Corte (se refiere a la Ley $N^{\circ} 23.774$ referida en la nota ${ }^{45}$ de este trabajo) y los cinco nuevos integrantes, seria igualmente malo intentar institucionalmente hacer lo mismo. Soy partidario de un cambio progresivo del plantel de la Corte. No puede modificarse bruscamente" (Diario La Nación, Buenos Aires, República Argentina, 11 de mayo de 2003, pág. 6). 
El primer magistrado que asumió en la Corte Suprema, durante el mandato de Kirchner, ha sido el Dr. Eugenio Zaffaroni ${ }^{55}$, en reemplazo del Dr. Julio Nazareno.

A los fines de cubrir la vacante del cargo que desempeñaba el $\mathrm{Dr}$. Guillermo López, fue postulada la Dra. Carmen Argibay ${ }^{56}$, cuya designación fue elevada por el Poder Ejecutivo al Senado, que todavía no ha prestado el acuerdo correspondiente.

Para la cobertura del cargo que ocupaba el Dr. Eduardo Moliné O'Connor, ha sido propuesta la Dra. Elena Highton de Nolasco, que se encuentra transitando la etapa de impugnación que vence el 31 de marzo de $2004^{57}$.

La ciudadanía reclama que este gobierno no pretenda tener "su Corte" y que su acción se enderece por el respeto absoluto de la independencia judicial.

b) Acerca de los decretos de necesidad y urgencia: una práctica consolidada.

La Constitución de la Nación Argentina prohíbe al Presidente emitir disposiciones de carácter legislativo, bajo pena de nulidad absoluta e insanable (art. 99 inc. 3.)

No obstante, la reforma constitucional de 1994 incorporó, entre las atribuciones del Presidente de la Nación Argentina, la de dictar decretos "de necesidad y urgencia». El art. 99, inc. 3., establece:

55 El Dr. Eugenio Zaffaroni, junto a los Dres. Rafael Bielsa (actual canciller), Marcos Salt y Maximiliano Rusconi, integraba el equipo de asesores en materia judicial de Néstor Kirchner durante su campaña electoral (información del Diario La Nación, Buenos Aires, República Argentina, 11 de mayo de 2003, pág. 6).

56 La Dra. Argibay sumó más de 10.000 oposiciones individuales y 130 apoyos de Organizaciones No Gubernamentales. Sus expresiones a favor del aborto y su propia definición como "atea militante" la hicieron portadora de numerosas críticas. En el plano internacional, la Asociación de Jueces para la Democracia se pronunció favorablemente por su candidatura. En el país, recibió opiniones positivas de la U.B.A. (Universidad de Buenos Aires), el CELS (Centro de Estudios Legales y Sociales), la Asociación Argentina de Mujeres de Carreras Jurídicas, la Asociación de Abogados de Buenos Aires, el Consejo Permanente de Decanos delas Facultades de Derecho de las Universidades Nacionales, entre otros.

57 La postulación de la Dra. Highton de Nolasco - Jueza de la Cámara Civil y Comercial de la Capital Federal (Sala "F") - habia recibido pocas opiniones desfavorables $y$, en general, cuenta con adhesión positiva en la sociedad y con el reconocimiento de sus pares. 
"[...] Solamente cuando circunstancias excepcionales hicieran imposible seguir los trámites ordinarios previstos por esta Constitución para la sanción de las leyes, y no se trate de normas que regulen materia penal, tributaria, electoral o el régimen de los partidos políticos, podrá dictar decretos de necesidad y urgencia, los que serán decididos en acuerdo general de ministros que deberán refrendarlos, conjuntamente con el jefe de gabinete de ministros.

El Jefe de Gabinete de ministros personalmente y dentro de los diez días someterá la medida a consideración de la Comisión Bicameral Permanente, cuya composición deberá respetar la proporción de las representaciones políticas de cada Cámara. Esta comisión elevará su despacho en un plazo de diez días al plenario de cada Cámara para su expreso tratamiento, el que de inmediato considerarán las Cámaras. Una ley especial sancionada con la mayoría absoluta de la totalidad de los miembros de cada Cámara regulará el trámite y los alcances de la intervención del Congreso ${ }^{58}$.

La Comisión Bicameral permanente no ha sido creada, así como tampoco ha sido dictada la ley especial que debe regular el trámite. No obstante, el actual gobierno no ha corregido la práctica exacerbada de esta facultad, de larga tradición en nuestra vida institucional ${ }^{59}$.

58 La Ley $N^{\circ} 24.309$ habilita a la convención constituyente entre los puntos a reforma (Núcleo de Coincidencias Básicas, pot. "G», la regulación de la facultad presidencial de dictar reglamentos de necesidad y urgencia, y procedimientos para agilización del trámite de discusión y sanción de las leyes.

59 Después de restaurada la democracia en 1983 hasta 1994 se sucedieron dos presidencias. En ambas se emplearon los decretos de necesidad y urgencia, que la Corte convalidó en diversos pronunciamientos. En la causa «Peralta, Luis Arcenio c. Poder Ejecutivo Nacional - Ministerio de Economía y Bco. Central s/ Amparo" (Fallos 313:1513), resuelta en 1990, la Corte fijó ciertas pautas para la procedencia de los decretos de necesidad y urgencia: a) una situación de grave riesgo social que pusiese en peligro la existencia misma de la Nación y el Estado; b) razonabilidad de las medidas dispuestas, es decir: que existiera relación entre los medios elegidos por la norma y los fines de ésta; examen de la proporcionalidad de las medidas y el tiempo de su vigencia; inexistencia de otros medios alternativos adecuados para lograr los fines buscados; y -por ultimoexigió la convalidación por el Congreso.

Comenta Sagüès que "Habitualmente se han dictado invocando la excepcionalidad de la medida adoptada y su impostergabilidad, y a menudo (pero no siempre) se ha reconocido en ellos que se apropiaban de competencias del Congreso. Estos decretos, habitualmente, terminaban disponiendo: "Dése cuenta al Honorable Congreso de la Nación", y algunos han tenido ratificación legislativa mediante ley de aprobación. Otros no han merecido tratamiento del Poder Legislativo" (Sagüés, Néstor, op.cit. nota ${ }^{4}$, pag. 611). 
La Procuración del Tesoro de la Nación ${ }^{60}$ ha rescatado, en diversos dictámenes, las pautas directrices que deben regir el dictado de los decretos de necesidad y urgencia, destacando que se trata de una facultad excepcional del Poder Ejecutivo, cuyo control - por tratarse de normas de naturaleza legislativa - le corresponde la Congreso de la Nación ${ }^{61}$.

Según un estudio del CEPPA (Centro de Estudios para Políticas Públicas Aplicadas) ${ }^{62}$, en sólo ocho meses de gobierno (desde el 25 de mayo de 2003 hasta el 25 de enero de 2004) el presidente Kirchner ha dictado cincuenta (50) decretos de necesidad y urgencia, superando a sus antecesores Fernando de la Rúa y Carlos S. Menem ${ }^{63}$, que habían firmado 30 y 44 decretos de necesidad y urgencia en igual período. Lo que llama la atención es que haya recurrido a esta facultad excepcional teniendo al Congreso a su favor; y sólo nueve de esos decretos fueron dictados estando el Congreso en receso. Por ello, se supone que "se trata de un estilo de gobierno, pero no de urgencias políticas".

La temática de los decretos de necesidad y urgencia es variada: modificaciones a la ley de presupuesto; fijación y aumento de salarios y de jubi-

60 Organo de máximo asesoramiento jurídico del Poder Ejecutivo Nacional y de representación judicial del Estado; resuelve conflictos interadministrativos, e interviene en la sustanciación de sumarios al personal superior de la Administración Pública (Ley $N^{\circ}$ 12.954; Decreto 34.952/47 y Ley $N^{\circ} 24.667$ ).

61 "La competencia del Poder Ejecutivo para emitir decretos de necesidad y urgencia reconoce su fundamento en el artículo 99 inciso $3 .^{\circ}$ de la Constitución Nacional. Los presupuestos que justifican su dictado son: a) debe tratare de una situación excepcional que, por su urgencia, impida seguir los trámites ordinarios para la sanción de las leyes; b) no deben referirse a materias vedadas por aquella manda constitucional; c) por tratarse del ejercicio de una competencia de naturaleza legislativa, el control de estas medidas corresponde al Congreso de la Nación" (Procuración del Tesoro de la Nación, Dictamen n. ${ }^{\circ}$ 157/03, 11 de marzo de 2003, Expte. $N^{\circ}$ 1569/01. Ministerio de Economía Colección de dictámenes 244:673, en Revista Enero-Junio 2003, pág. 84).

«Atendiendo al texto constitucional plasmado en la reforma del año 1994, los decretos de necesidad y urgencia deben estar sometidos al pertinente contralor del Poder Legislativo de la Nación, a quien corresponde pronunciarse acerca de los extremos - de valoración política- que habilitan el ejercicio dela facultad excepcional del Poder Ejecutivo, asi como la oportunidad, mérito y conveniencia de su contenido; la Constitución Nacional atribuye al legislador una excluyente intervención en el contralor de los decretos de necesidad y urgencian (P.T.N., Dictamen . $^{\circ} 238 / 03,15$ de abril de 2003, Expte. N. ${ }^{\circ} 1100 / 02$. Comisión Nacional de Valores -Colección de dictámenes 245:111, en Revista Enero-Junio 2003, pág. 83).

62 Publicado en Diario La Nación, Buenos Aires, República Argentina, domingo 14 de marzo de 2004, pág. 23.

63 El informe alerta que «Menem, durante sus diez años de gobierno (1989-1999) firmó el récord de 545 decretos de necesidad y urgencia, lo que le valió la crítica de haber gobernado por decreto". 
laciones mínimas; aumento de subsidios para Jefes y Jefas de Hogar para las fiestas de fin de año; la restitución a las Administradores de Fondos de Jubilaciones y Pensiones (AFJP) de las facultades de control de la recaudación previsional; la prohibición a las empresas telefónicas de cortar el servicio por falta de pago en las zonas inundadas de la provincia de Santa Fe; la modificación de la ley de ministerios; la prórroga de los topes para sueldos de funcionarios; la prórroga de la emergencia sanitaria y ocupacional; $Y$ otras medidas que debería haber adoptado el Congreso, como la aprobación de la farmacopea para este año (la totalidad de los medicamentos que se pueden vender en la Argentina y su calificación técnica).

El Congreso también es responsable de este avance del Poder Ejecutivo, al no cumplir con el control que le asigna el propio texto de la Constitución. Una vez firmado el decreto en acuerdo general de ministros, el Jefe de Gabinete de Ministros, personalmente y dentro de los diez días de dictado el decreto, debe someterlo a consideración de la Comisión Bicameral Permanente que - como adelantamos - aún no ha sido creada ni reglamentado el tratamiento de la intervención del Congreso, lo que ha suscitado dudas en la doctrina constitucional acerca de la validez o no del ejercicio de la facultad presidencial, coincidiendo en que no es viable la sanción ficta de la legislación de necesidad y urgencia, sino que requiere un tratamiento expreso, de acuerdo al propio texto de la Constitución cuando dispone que "La voluntad de cada Cámara debe manifestarse expresamente; se excluye en todos los casos la sanción tácita o ficta» (art. 82).

Ante la ineficiencia, incapacidad o desinterés del órgano legislativo, el órgano ejecutivo - haciendo gala de su dinámica política - ensancha sus prerrogativas y se transforma en un legislador ágil difícil de contrarrestar. La responsabilidad de restablecer las reglas de juego y el equilibrio de las relaciones de poder para encauzar la vida política de la Nación es compartida. La sociedad argentina está expectante que la reacción llegue a tiempo.

\section{REFLEXIÓN FINAL.}

La Constitución Nacional configura el diseño institucional de la República y es, en palabras de García de Enterría, "... el contexto necesario de todas las leyes $y$ de todas las normas ...." ${ }^{64}$. Como ha advertido

64 Garcia de Enterría, Eduardo, La Constitución como norma y Tribunal Constitucional, Civitas S.A., 1985, Madrid, pág. 20. 
Martino ${ }^{65}$, "las elecciones no son una conditio per quam, sino un medio de la democracia y, para adquirir significado, deben ser colocadas en un contexto histórico, en un sistema político, a falta de los cuales los vicios y las virtudes que se predican para cada sistema electoral carecen de sustento". Estimo que no hay sistemas perfectos, sino funcionales y perfectibles. Habrá que permitir que el sistema transite para poder evaluar los beneficios y desventajas del sistema electoral presidencial que la Nación Argentina ha adoptado. $Y$ es deseable que el camino no haya sido errado.

La Corte Suprema podrá trascender sin excusas las necesarias alternancias político partidarias en el gobierno nacional, porque su fuerza será su independencia y su compromiso con la sociedad. La ciudadanía, entonces, no sólo estará dispuesta a cumplir con sus obligaciones legales sino también a exigir el cumplimiento de sus derechos $y$ garantías.

Nuestra Constitución diseña una forma republicana de gobierno y asegura la división de poderes. Las libertades constitucionales y la igualdad son lo que dan sentido a todo lo demás. Un buen gobierno debe subordinarse a la ley y actuar en función del interés público general. Con acierto sostiene Ferrajoli que "[...] el diseño del Estado de Derecho [...] exige el sometimiento de todos los poderes públicos, incluido el legislativo, a normas no sólo formales [...] sino también sustanciales, como son precisamente los principios y derechos fundamentales" 66 . Las reglas relativas a los poderes públicos, su elección y funcionamiento son la garantía para que las declaraciones y principios que alberga la Constitución no sean declamaciones utópicas. Y en ese sentido, nuestra Ley Fundamental contiene todos los elementos necesarios para asegurar la permanencia de la democracia: soberanía popular ${ }^{67}$-que delega

65 Martino, Antonio A., Sistemas electorales, Editorial Advocatus, 1999, pág. 312.

66 FerRAJOL, Luigi, Derechos y Garantías -La ley del más débil, EditorialTrotta, 3. ${ }^{\circ}$ edición, Madrid, España, 2002, pág. 113.

67 «Las declaraciones, derechos y garantias que enumera la Constitución, no serán entendidos como negación de otros derechos y garantías no enumerados, pero que nacen del principio de la soberanía del pueblo y de la forma republicana de gobierno" [énfasis propio] (Constitución Nacional, art. 33). En esta norma "se plasmó la concepción iusnaturalista que predica la existencia de derechos anteriores a cualquier organización social, ligada al principio dela soberanía del pueblo" (cfr. Gelli, ... op.cit., pág. 299). El art. 37 refuerza esta posición: «Esta Constitución garantiza el pleno ejercicio de los derechos políticos, con arreglo al principio de la soberanía popular, y de las leyes que se dicten en consecuencia [...]". 


\section{en los órganos expresamente constituidos par su ejercicio-68; partici- pación popular la través de la iniciativa popular y de la consulta popu-}

68 «El pueblo no delibera ni gobierno, sino por medido de sus representantes y autoridades creadas por esta constitución. Toda fuerza armada o reunión de personas que se atribuya los derechos del pueblo y peticione a nombre de éste, comete delito de sedición" (art. 22 Constitución Nacional). Este principio de representación deriva de la declaración contenida en el art. $1{ }^{\circ}$ de la Ley Fundamental: "La Nación Argentina adopta para su gobierno la forma representativa republicana federal, según la establece la presente Constitución".

69 Estas modalidades de participación popular fueron incorporados con la reforma constitucional de 1994 como "mecanismos de democracia semidirecta" (Ley de declaración de la necesidad de la reforma N. ${ }^{\circ} 24.309$ - Núcleo de Coincidencias Básicas - Temas habilitados por el Congreso Nacional para su debate por la Convención Constituyente - Pto. "Co).

Con relación a la iniciativa popular, el art. 39 de la C.N. (incorporado en la reforma de 1994) dispone: "Los ciudadanos tienen el derecho de iniciativa para presentar proyectos de ley en la Cámara de Diputados. El Congreso deberá darles expreso tratamiento dentro del término de doce meses. El Congreso, con el voto de la mayoría absoluta de la totalidad de los miembros de cada Cámara, sancionará una ley reglamentaria que no podrá exigir más del tres por ciento del padrón electoral nacional, dentro del cual deberá contemplar una adecuada distribución territorial para suscribir la iniciativa. No serán objeto de iniciativa popular los proyectos referidos a reforma constitucional, tratados internacionales, tributos, presupuesto y materia penal». En cumplimiento de esta norma - aunque excediendo los límites temporales que estableció la cláusula transitoria tercera (dieciocho meses a partir de la sanción de la Constitución reformada, es decir, del 22/08/94) - , el Congreso de la Nación sancionó la Ley n. ${ }^{\circ}$ 24.747 (B.O. 24/12/1996), que reglamenta este derecho.

La consulta popular está contemplada en el art. 40 de nuestra Carta Magna: «EI Congreso, a iniciativa de la Cámara de Diputados, podrá someter a consulta popular un proyecto de ley. La Ley de convocatoria no podrá ser vetada. E voto afirmativo del proyecto por el pueblo de la Nación lo convertirá en ley y su promulgación será automática. El Congreso o el presidente de la Nación, dentro de sus respectivas competencias, podrán convocar a consulta popular no vinculante. En este caso el voto no será obligatorio. El Congreso, con el voto de la mayoría absoluta de la totalidad de los miembros de cada Cámara, reglamentará las materias, procedimientos y oportunidad de la consulta popularn. Este derecho ha sido reglamentado por Ley N. ${ }^{\circ} 25.342$ (B.O. 27/6/2001).

70 La Constitución de la Nación Argentina estructura una división de poderes en Legislativo (Cámara de Diputados y Cámara de Senadores - art. 44-), Ejecutivo (a cargo de un Presidente - art. 87), y el Judicial (a cargo de la Corte Suprema y demás tribunales inferiores que el Congreso estableciere en el territorio de la Nación - art. 108), con un sistema de controles interorgánicos. Ello debe complementarse con las disposiciones contenidas en el artículo 29: “El Congreso no puede conceder al Ejecutivo Nacional, ni las legislaturas provinciales a los gobernadores de provincia, facultades extraordinarias, ni la suma del poder público, ni otorgarles sumisiones o supremacías por las que la vida, el honor, o las fortunas de los argentinos queden a merced de gobiernos o persona alguna. Actos de esta naturaleza llevan consigo una nulidad insanable, y sujetarán a los que los formulen, consientan o firmen, a la responsabilidad y pena de los infames traidores a la patrian. A su vez, el Presidente de la Nación «en ningún caso puede ejercer funciones judiciales, arrogarse el conocimetno de causas pendientes ni restablecer las fenecidas (art. 109 C.N.). Tampoco puede el Presidente de la Nación emitir disposiciones de carácter legislativon (art. 99 inc. 3., 2. párr.). No obstante, esta prohibición ha sido atemperada con la delegación legislativa que habilita el art. 76, con la reforma de 1994: "Se prohíbe la delegación legislativa en el Poder Ejecutivo, salvo en materias determinadas de administración o de emergencia pública, con plazo fijado para su ejer- 
$\left.\operatorname{lar}^{69}\right)$; división de poderes ${ }^{70}$; austeridad republicana ${ }^{71}$; periodicidad en la función pública ${ }^{72}$; pluralismo ${ }^{73}$; respeto por las minorias ${ }^{74}$; publicidad de:

cicio y dentro de las bases de la delegación que el Congreso establezca [...]"; como así también con la posibilidad de dictar decretos de necesidad y urgencia: "Solamente cuando circunstancias excepcionales hicieran imposible seguir los trámites ordinarios previstos por esta Constitución para la sanción de las leyes, y no se trate de normas que regulen materia penal, tributaria, electoral o el régimen de los partidos políticos, (el Presidente de la Nación) podrá dictar decretos de necesidad y urgencia, los que serán decididos en acuerdo general de ministros que deberán refrendarlos, conjuntamente con el jefe de gabinete de ministros [...]".

${ }^{71}$ Entre los nuevos derechos incorporados con la reforma constitucional de 1994, el art. 36, en su última parte, dispone: «[...] El Congreso sancionará una ley sobre ética pública para el ejercicio de la función públicam. En tal sentido, se dictó la Ley de Ética de la Función Pública $N^{\circ} 25.188$ (1/11/1999), reglamentada por Decreto $n^{\circ} 164 / 99$ (B.O. 7/1/2000). Esta Ley exige la "austeridad republicana" como modo de ejercicio del poder, que complementa con los valores de honestidad, probidad, rectitud, buena fe $y$ transparencia en la función pública.

72 La Constitución de la Nación Argentina contempla la periodicidad de los mandatos para el cargo de Presidente y vicepresidente (Poder Ejecutivo - art. 90 ), $v$ para los legisladores (los diputados duran cuatro años (art. 50) y los senadores, seis años (art. 56), y ambos son reelegibles indefinidamente). No asi para los jueces, que son inamovibles mientras dure su buena conducta (art: 110). No obstante, respecto de los jueces, la reforma constitucional de 1994 innovó en la implementación de «un nuevo nombramiento (por el Presidente de la Nación), precedido de igual acuerdo (del Senado, en sesión pública, con el voto de dos tercios de sus miembros presentes) será necesario para mantener en su cargo a cualquiera de esos magistrados (de la Corte Suprema y demás tribunales inferiores), una vez que cumplan. la edad de setenta y cinco años. Todos los nombramientos de magistrados cuya edad sea la indicada o mayor se harán por cinco años, y podrán ser repetidos indefinidamente, por el mismo trámiten (art. 99, inc. 4). Esta cláusula constitucional fue declarada nula por la Corte Suprema de Justicia de la Nación, en el año 1999, en el caso "Fayt» (el Dr. Carlos S. Fayt era uno de los ministros de la Corte, que más tarde renunció ante el pedido de juicio político), sosteniendo que "la limitación por edad vulneraba la independencia de los magistrados" (CSJN, Fallos 322:1616). La nulidad alcanzó a la cláusula transitoria undécima que expresa: «La caducidad de los nombramientos y la duración limitada previstas en el artículo 99 inciso 4 entrarán en vigencia a los cinco años de la sanción de esta reforma constitucional»:

${ }^{73}$ La Constitución de Nacional es la ley que une a todos, pese a la diversidad, en una: sociedad plural.

${ }^{74}$ La Constitución de la Nación Argentina - a partir de 1994- incorpora el tercer senador en representación de las minorías. El Senado de la Nación -que representa a las provincias y a la Ciudad Autónoma de Buenos Aires, se compone desde entonces por dos senadores por el partido que obtenga el mayor número de votos, y por un senador, por el partido: político que le siga en número de votos (art. 54 C.N.).

75 La publicidad de los actos de gobierno es una de las caracteristicas del régimen republicano de gobierno que consagra el art. $10^{\circ}$ de la C.N. Comprende, entre otras facetas, el: derecho a conocer los datos personales registrados en bancos de datos públicos. El art. 43 , 3. ${ }^{\circ}$ párr., de la C.N. expresa: « [...] Toda persona podrá interponer esta acción lexpedita y rápida de amparol para tomar conocimiento de los datos a ella referidos y de su finalidad, que consten en registros o bancos de datos públicos, [...] y en caso de falsedad o discriminación, para exigir la supresión, rectificación, confidencialidad o actualización de aquéllos [...]). Esta cláusula constitucional ha sido reglamentada mediante Ley . $^{\circ} 25.326$ (B.0. 2/11/2000), cuyo comentario excede el alcance de este trabajo. En algunos casos, se prohíbe o se limita la 
los actos de gobierno ${ }^{75}$; responsabilidad de los funcionarios públicos ${ }^{76}$; preeminencia de la Constitución ${ }^{77}$. En definitiva, sólo resta que todos absolutamente todos - asumamos el compromiso de observar con fidelidad sus preceptos, para hacer realidad el noble propósito que alberga su Preámbulo: asegurar los beneficios de la libertad para nosotros, para nuestra posteridad y para todos los hombres del mundo que quieran habitar en el suelo argentino.

\section{San Juan, Argentina, 26 de marzo de 2004.}

publicidad de los actos de gobierno por tiempo determinado (por ejemplo, durante la campaña electoral, la publicidad de los actos de gobierno no podrán contener elementos que promuevan expresamente la captación del sufragio a favor de ninguno de los candidatos a cargos públicos electivos nacionales, y se prohíbe, durante los 7 días anteriores a la fecha del comicio, la realización de actos de gobierno que puedan captar el sufragio (Ley 25.610, incorpora art. 64 quater al Código Electoral Nacional aprobado por Ley N. $\left.{ }^{\circ} 19.945\right)$. El mismo cuerpo normativo establece que "Los funcionarios públicos que autorizaren o consintieran la publicidad de los actos de gobierno en violación de ka prohibición establecida en el artículo 64 quater, serán pasibles de inhabilitación de 1 a 10 años para el ejercicio de cargos públicos (art. 11 Ley 25.610, incorporado como art. 133 bis de la Ley N. ${ }^{\circ}$ 19.945).

76 La Constitución de la Nación Argentina establece que «El Presidente de la Nación [...] Inc. 1. Es el jefe supremo de la Nación, jefe de gobierno y responsable político de la administración general del pais". El Jefe de Gabinete de Ministros es el encargado de ejercer la administración general del país, con responsabilidad política ante el Congreso de la Nación" (art. 100, inc. 1, C.N.). En tal sentido, el Jefe de Gabinete de Ministros debe concurrir al Congreso al menos una vez por mes, alternativamente a cada una de las Cámaras, para informar de la marcha del gobierno. Puede ser interpelado a los efectos del tratamiento de una moción de censura, por el voto dela mayoría absoluta de la totalidad de los miembros de cualquiera de las Cámaras, y ser removido por la mayoría absoluta de los miembros de cada una de las Cámaras (art. 101 C.N.), sin perjuicio de la facultad de remoción que asiste al Presidente de la Nación (art. 99 inc. 7. C.N.). Los mecanismos: el juicio político, para la destitución del presidente de la Nación, vicepresidente, ministros, y jueces de la Corte Suprema (arts. 53, 59 y 60 C.N.); y la corrección y remoción de legisladores a través de la decisión de cada una de las Cámaras (art. 66); el jurado de enjuiciamiento para la remoción de los jueces de tribunales inferiores (art. 115), con la intervención del Consejo de la Magistratura que tiene atribuciones para "decidir la apertura del procedimiento de remoción de magistrados, en su caso ordenar la suspensión, y formular la acusación correspondiente (art. 114 inc. 6. C.N.).

77 Los principios de supremacía constitucional y de jerarquía de las fuentes están contenidos en el art. 31 de la Constitución Nacional que consagra: "Esta Constitución, las leyes de la Nación que en su consecuencia se dicten por el Congreso y los tratados con las potencias extranjeras son la ley suprema de la Nación; y las autoridades de cada provincia están obligadas a conformarse a ellas, no obstante cualquier disposición en contrario que contengan las leyes o constituciones provinciales, salvo para la Provincia de Buenos Aires, los tratados ratificados después del Pacto del 11 de noviembre de 1859". 